\title{
OPTIMALISASI PERILAKU PEMENUHAN NUTRISI PADA IBU HAMIL TRIMESTER SATU MELALUI PENYULUHAN
}

\author{
Dewi Andriani \\ Akademi Keperawatan Adi Husada Surabaya \\ andridewi64@gmail.com
}

\begin{abstract}
ABSTRAK
Asupan nutrisi merupakan salah satu kunci keberhasilan selama masa kehamilan. Jika asupan nutrisi selama kehamilan tidak terpenuhi, plasenta akan kekurangan zat makanan sehingga akan mengurangi kemampuannya dalam mensintesis zat-zat yang dibutuhkan oleh janin. Beberapa faktor penting dalam pemenuhan nutrisi ibu hamil adalah perilaku ibu hamil. Oleh karena itu, intervensi penyuluhan dan perilaku ibu hamil tentang asupan nutrisi sangat diperlukan untuk keberhasilan kehamilannya.Tujuan penelitian ini bertujuan mengidentifikasi pengaruh penyuluhan terhadap perubahan perilaku pemenuhan nutrisi pada ibu hamil trimester satu di Puskesmas Gading Surabaya.Desain penelitian yang digunakan adalah pre-post one group design.Teknik sampling yang digunakan adalah purposive sampling dan jumlah sampel sebanyak 20 responden. Data diperoleh melalui lembar kuesioner perilaku dan hasil dianalisis dengan uji Wilcoxon Signed Rank Test. Karakteristik responden adalah sebagian besar berusia 21-25 tahun, pendidikan SMA, tidak bekerja, kontrol teratur, berpenghasilan $>$ UMK. Hasil uji statistik menunjukkan ada pengaruh pemberian penyuluhan terhadap perubahan perilaku ibu hamil trimester satu dalam pemenuhan nutrisi di Puskesmas Gading Surabaya.Untuk mengoptimalkan perubahan perilaku dapat diberikan tidak hanya penyuluhan namun metode FGD dan demontrasi.
\end{abstract}

Kata kunci: penyuluhan, perilaku ibu hamil trimester satu, pemenuhan nutrisi

\section{ABSTRACT}

Nutritional intake is one of the keys to success during pregnancy. If the nutritional intake during pregnancy are not fullfilled, the placenta will be a shortage of nutrients so that it will reduce its ability to synthesize substances that are needed by the fetus. Some of the important factors in the nutrition of pregnant women are counseling and behavioral interventions pregnant mothers about nutrition. Therefore, intervention and behavioral counseling pregnant women about nutrition is indispensable for the success of her pregnancy. The purpose of this study to identified effect of health education on nutrition behavior change in one trimester pregnant women in Ivory PHC Surabaya. The study design used is a one-group pre-post design. Sampling technique used is purposive sampling and the total sample of 20 respondents. Data were obtained through a questionnaire sheet behavior and the results were analyzed by Wilcoxon Signed Rank Test. Characteristics of respondents are mostly 21-25 years old, high school education, no work, regular controls, income> UMK. Statistical analysis showed no effect of health education on behavior change trimester pregnant women in fulfillment of one nutrient in Ivory PHC Surabaya. To optimize the behavior change can be given not only counseling but the method FGD and demonstrations.

\section{Keywords: Health education, $1^{\text {rd }}$ trimester pregnant women, nutritional intake}

\section{PENDAHULUAN}

Setiap ibu hamil memiliki kebutuhan nutrisi yang berbeda. Kebutuhan nutrisi bukan hanya ditinjau dari porsi makanan, tetapi juga ditentukan pada mutu intake nutrisi yang terkandung didalamnya. ${ }^{1}$ Awal kehamilan trimester satu mual dan muntah pada pagi hari (morning sicknes) sering dialami. Perubahan perilaku dan perubahan fisik ibu hamil terjadi karena perubahan hormon. Hormon Human Chorionic Gonadotropin (HCG) memicu terjadinya mual, diproduksi oleh plasenta yang sedang berkembang memastikan bahwa induk telur memproduksi estrogen dan progesteron sampai plasenta matang. Peningkatan kadar hormon minimbulkan keluhan sakit kepala, pusing, air ludah yang berlebihan, payudara yang membesar dan mudah lelah. Perubahan psikologis dapat berupa: merasa tidak sehat dan benci kehamilannya, selalu memperhatikan setiap perubahan yang terjadi pada tubuhnya, mencari beberapa tanda untuk lebih menyakinkan bahwa dirinya sedang hamil, mengalami gairah seks yang lebih tinggi tapi libido turun, khawatir kehilangan bentuk tubuh, membutuhkan penerimaan kehamilannya oleh keluarga dan ketidakstabilan emosi/suasana hati. 
Perilaku manusia merupakan hasil dari segala macam pengalaman serta interaksi manusia dengan lingkungannya yang terwujud dalam bentuk pengetahuan, sikap dan tindakan. Perilaku merupakan respon / interaksi seorang individu terhadap stimulus yang berasal dari luar mamupun dari dalam dirinya. Respon ini dapat bersifat pasif (tanpa tindakan) maupun aktif (melakukan tindakan). Sesuai dengan batasan ini, perilaku kesehatan dapat di rumuskan sebagai bentuk pengalaman dan interaksi individu dengan lingkungannya, khususnya yang menyangkut pengetahuan dan sikap tentang kesehatan.

Penyuluhan kesehatan merupakan penambahan pengetahuan dan kemampuan seseorang melalui tehnik praktek belajar atau instruksi dengan tujuan mengubah atau mempengaruhi perilaku manusia secara individu, kelompok maupun masyarakat untuk dapat lebih mandiri dalam mencapai tujuan hidup sehat.

Fatimah, Hadju, Bahar dan Abdullah (2012), dalam penelitian mereka terhadap 200 orang ibu hamil menunjukkan bahwa pola makan ibu hamil mencerminkan pola makan tidak sehat. Pemenuhan nutrisi bagi ibu hamil memegang peran signifikan dalam menurunkan Angka Kematian Ibu (AKI), Angka Kematian Bayi (AKB) dan menentukan kualitas anak yang akan dilahirkan. Status kesehatan dan nutrisi ibu hamil di Indonesia tergolong buruk jika dibandingkan Negara ASEAN lainnya, apalagi dibandingkan negara maju. Resiko kematian ibu karena melahirkan adalah 1 dari 65 , sedangkan Thailand 1 dari 1000 ibu. Angka kematian ibu menurut SDKI antara 1998-2002 mengalami penurunan menjadi 307 per 100.000 kelahiran hidup dari 390 per 100.000 kelahiran hidup pada tahun 1995 dan sekarang AKI masih 228 per 100.000 kelahiran hidup, 55\% kematian ibu disebabkan oleh pendarahan dan pre-eklamsia yang terkait erat dengan kondisi nutrisi buruk selama hamil (Prasetyawati, 2012).

Kehamilan trimester satu merupakan pembentukan organ tubuh janin (Atikah, 2009). Nutrisi sangat berperan dalam pertumbuhan maupun aktivitas janin selain itu berperan juga dalam kondisi ibu selama kehamilan. Asupan nutrisi menurunan dapat menyebabkan malnutrisi ibu, yang menjadi salah satu penyebab retardasi pertumbuhan intrauterine dan melahirkan bayi bobot rendah. Bayi yang kekurangan nutrisi selama kehamilan karena asupan kebutuhan nutrisi tidak terpenuhi menyebabkan penurunan sejumlah sel otak. Tujuan dari penelitian ini adalah mengidentifikasi pengaruh penyuluhan terhadap perubahan perilaku pemenuhan nutrisi pada ibu hamil trimester satu di Puskesmas Gading Surabaya.

\section{METODE PENELITIAN}

Desain penelitian yang digunakan adalah pre-post one group design dengan pendekatan cross sectional. Penelitian ini populasinya adalah seluruh ibu hamil di wilayah Puskesmas Gading dengan sampel penelitian ini adalah ibu hamil trimester 1 yang berkunjung ke BKIA dengan usia $\leq 35$ tahun yang didapatkan melalui tehnik purposive sampling. Analisa data Uji Wilcoxon Sign Rank Test dengan $\alpha<0,05$. Penelitian dilaksanakan pada Bulan Mei 2016.

\section{HASIL PENELITIAN}

\section{Data Umum}

Tabel 1. Distribusi Karakteristik Responden Penelitian

\begin{tabular}{clcc}
\hline No. & Usia Responden & n & \% \\
\hline 1 & Umur (Tahun) & & \\
& $21-25$ Thn & 8 & 40 \\
& $26-30$ Thn & 5 & 25 \\
& $31-35$ Thn & 7 & 35 \\
2 & Pendidikan & 3 & \\
& SD & 6 & 30 \\
& SMP & 7 & 35 \\
& SMA & 4 & 20 \\
& PT & & \\
3. Pekerjaan & 11 & 55 \\
& Tidak Bekerja & 7 & 10 \\
& Swasta & 2 & 35 \\
& PNS & & \\
4. Kontrol & 19 & 95 \\
& Teratur & 1 & 5 \\
& Tidak Teratur & & \\
5. Penghasilan & 4 & 20 \\
& < UMK & 6 & 30 \\
& =UMK & 10 & 50 \\
\hline
\end{tabular}

Tabel 1 menunjukkan karakteristik responden berdasarkan umur 21-25 tahun sebanyak 8 responden $(40 \%)$, berpendidikan SMA 7 responden (35\%), tidak bekerja 11 responden (55\%), keontrol teratur 19 responden (95\%) dan berpenghasilan lebih dari UMK 10 responden $(50 \%)$.

\section{Data Khusus}

Tabel 2.Tabulasi Perilaku Pre dan Post penyuluhan ibu hamil Trimester IdiPuskesmas Gading Surabaya bulan Mei 2016 


\begin{tabular}{|c|c|c|c|c|c|}
\hline \multirow{2}{*}{ No. } & \multirow{2}{*}{ Perilaku } & \multicolumn{2}{|c|}{ Pre } & \multicolumn{2}{|c|}{ Post } \\
\hline & & $\mathrm{n}$ & $\%$ & $\mathbf{n}$ & $\%$ \\
\hline 1 & Baik & 1 & 5 & 12 & 60 \\
\hline 2 & Cukup & 7 & 35 & 6 & 30 \\
\hline \multirow[t]{2}{*}{$\frac{2}{3}$} & Kurang & 12 & 60 & 2 & 10 \\
\hline & Total & 20 & 100 & 20 & 100 \\
\hline & Wilcoxon S & $\begin{array}{l}d R \\
0,05\end{array}$ & $k T e s$ & $p=$ & \\
\hline
\end{tabular}

Table 2 menunjukkan bahwa sebagian besar perilaku pemenuhan kebutuhan nutrisi ibu hamil sebelum dilakukan penyuluhan adalah kurang yaitu 12 responden $(60 \%)$ dan setelah dilakukan penyuluhan didapatkan hasil sebagian besar reponden memiliki perilaku baik yaitu 12 reponden (60\%). Hasil yang didapatkan dari uji Wilcoxon Signed Rank Test diketahui nilai $\mathrm{p}=0,03 \quad(\alpha<0,05)$ artinya H1 diterima, dapat disimpulkan ada pengaruh pemberian penyuluhan dengan perilaku ibu hamil Trimester I dalam pemenuhan kebutuhan nutrisi di Puskesmas Gading Surabaya.

\section{PEMBAHASAN}

\section{Sebelum diberi penyuluhan}

Berdasarkan hasil penelitian di Puskemas Gading Surabaya pada Bulan Mei 2016 menunjukkan hasil sebanyak 12 responden $(60 \%)$ dalam kriteria kurang. Hal ini menunjukkan sebagian besar dari ibu hamil sebelum diberikan intervensi penyuluhan bisa dengan mudah di pengaruhi perilaku ke arah yang lebih baik untuk memenuhi kebutuhan nutrisi di periode kehamilan trimester 1.Penambahan pengetahuan dan kemampuan seseorang melalui tehnik praktek belajar atau instruksi dengan tujuan mengubah atau mempengaruhi perilaku manusia secara individu, kelompok maupun masyarakat untuk dapat lebih mandiri dalam mencapai tujuan hidup sehat. Tingkatan Perilaku menurut Notoatmodjo (2007), perilaku terdiri dari empat tingkatan yaitu: menerima (receiving), merespons (responding), menghargai (valuing) dan bertanggung jawab (responsible). Adapun faktor yang mempengaruhi perilaku, antara lain: umur, pendidikan terakhir, penghasilan keluarga, pekerjaan, umur kehamilan, kontrol kehamilan.

Tingkat pendidikan responden terbanyak adalah SMA sebanyak 7 orang $(35 \%)$ dan paling sedikit dengan pendidikan SD sebanyak 3 orang $(15 \%)$. Pendidikan berarti bimbingan yang diberikan oleh seseorang terhadap orang lain menuju kearah cita-cita, pendidikan merupakan faktor paling penting karena dengan pendidikan akan menimbulkan perilaku positif. Pendidikan menengah atas akan membuat seseorang lebih mudah untuk bisa menyerap dan mengaplikasikan informasi yang diterima sehingga ibu hamil akan mau melakukan sesuatu yang berkaitan dengan pemenuhan nutrisi di periode trimester 1 .
Penghasilan keluarga di dapatkan sejumlah 10 orang $(50 \%)$ berpenghasilan $=$ UMR sedangkan paling sedikit sejumlah 4 orang $(20 \%)<$ UMR. Meningkatnya pendapatan sama halnya memperbesar peluang untuk membeli pangan yang berkualitas yang lebih baik. Sebaliknya penurunan pendapatan akan menyebabkan penurunan dalam hal kualitas pangan yang dibeli. ${ }^{10}$ Pendapatan mempengaruhi kebutuhan pangan pada ibu hamil dalam memenuhi nutrisi yang di butuhkan di periode trimester 1.

Berdasarkan jenis pekerjaan di dapatkan sejumlah 11 orang $(55 \%)$ yang tidak memiliki pekerjaan. Pekerjaan adalah kebutuhan yang harus dilakukan terutama untuk menunjang kehidupannya dan keluarganya untuk mencapai tujuan hidup yang lebih baik. Seseorang yang mempunyai pekerjaan yang penting dan memerlukan aktivitas umumnya merupakan kegiatan yang menyita waktu. Jadi masyarakat yang sibuk hanya memiliki sedikit waktu, responden mayoritas adalah ibu rumah tangga, sehingga memiliki waktu luang yang lebih banyak dan dapat memeriksakan kehamilannya di puskesmas wilayah tempat tinggalnya.

\section{Sesudah diberi penyuluhan}

Pada Ibu Hamil Trimester 1 menunjukkan hasil sebanyak 12 responden $(60 \%)$ dalam kriteria baik dan 8 responden $(40 \%)$ dalam kriteria cukup. Hal ini menunjukkan sebagian besar dari ibu hamil setelah diberikan intervensi penyuluhan perilaku ibu hamil ke arah yang lebih baik untuk memenuhi kebutuhan nutrisi di periode kehamilan trimester 1.

Berdasarkan umur kehamilan di dapatkan 9 orang $(45 \%)$ umur kehamilannya 2 bulan dan paling sedikit 3 orang (15\%) umur kehamilannya 1 bulan. Masa kehamilan dimulai dari konsepsi sampai lahirnya janin. Lamanya hamil normal adalah 280 hari (40 minggu 9 bulan 7 hari) dihitung dari haid pertama haid terakhir. Kehamilan dibagi dalam 3 triwulan yaitu triwulan pertama dimulai dari konsepsi sampai 3 bulan, triwulan kedua dari bulan keempat sampai 6 bulan, triwulan ketiga dari 7 bulan sampai 9 bulan. ${ }^{8}$ Ibu hamil pada trimester 1 cenderung mengalami moring sickness (mual muntah) terutama pada umur kehamilan 2 bulan dikarenakan Hormon Human Chorionic Gonadotropin (HCG) meningkat.

Responden berdasarkan kontrol kehamilan di dapatkan 19 orang $(95 \%)$ kontrol kehamilannya secara teratur dan paling sedikit 1 orang $(5 \%)$ kontrol kehamilannya tidak teratur. Pemeriksaan kehamilan adalah kegiatan yang diberikan untuk ibu sebelum melahirkan atau atau dalam masa kehamilan. Pemeliharaan kehamilan merupakan suatu upaya yang dilakukan dalam pemeliharaan terhadap kesehatan ibu dan janinnya. ${ }^{5}$ Pemeriksaan pertama dilakukan segera setelah diketahui terlambat haid. Memeriksakan kehamilan secara teratur dapat mencegah terjadinya komplikasi dan risiko pada ibu hamil dan janinnya.

\section{Pengaruh penyuluhan terhadap perilaku}


Berdasarkan hasil penelitian di Puskemas Gading Surabaya pada bulan Mei 2016 tentang Hubungan Intervensi Penyuluhan Dengan Perilaku Pemenuhan Nutrisi Pada Ibu Hamil Trimester 1 menunjukkan hasil uji Wilcoxon Rank Test tingkat signifikasi $\mathrm{Z}=-2,985$ dengan $\mathrm{P}$ value $=0,003$. Dari uji statistik diperoleh hasil uji signifikan/bermakna, adanya pengaruh antara sampel yang diteliti, pada taraf signifikasi tertentu. Hal ini menunjukkan bahwa antar variabel terdapat pengaruh yang bersifat kuat.Sebelum penyuluhan ibu hamil mempunyai perilaku kurang dari pemenuhan nutrisi pada ibu hamil trimester 1 . Nutrisi ibu hamil trimester 1 sangat di perlukan untuk pembentukan organ janin sementara itu pada kondisi tersebut sering terjadi ibu hamil mengalami mual muntah sehingga nutrisi ibu hamil tidak terpenuhi. Setelah diberikan penyuluhan ibu hamil telah memiliki pemahaman yang lebih baik tentang pentingnya nutrisi bagi pertumbuhan dan perkembangan janin. Ibu hamil memahami dan mengaplikasikan ke perilaku baik sehingga ibu hamil dapat memenuhi kebutuhan nutrisi pada trimester 1 .

\section{SIMPULAN}

1. Perilaku ibu hamil tentang pemenuhan nutrisi pada trimester 1 sebelum diberikan intervensi penyuluhan sebagian besar baik sebanyak 1 orang $(5 \%)$, cukup sebanyak 7 orang $(35 \%)$ dan kurang sebanyak 12 orang $(60 \%)$.

2. Perilaku ibu hamil tentang pemenuhan nutrisi pada trimester 1 sesudah diberikan penyuluhan sebagian besar baik sebanyak 12 orang $(60 \%)$ dan cukup sebanyak 6 orang $(30 \%)$ dan kurang sebanyak 2 orang $(10 \%)$.

3. Berdasarkan uji statistik Wilcoxon Rank Test didapatkan tingkat signifikasi $\mathrm{Z}=-2,985$ dengan $\mathrm{P}$ value $=0,003$ hal tersebut menunjukkan pengaruh yang kuat antara perilaku sebelum intervensi penyuluhan dan sesudah intervensi penyuluhan.

\section{SARAN}

Untuk mengoptimalkan perubahan perilaku dapat diberikan tidak hanya penyuluhan namun metode FGD dan demontrasi. Diharapkan peran aktif keluarga terutama suami memotivasi ibu hamil untuk pemenuhan kebutuhan nutrisi pada trimester satu.

\section{DAFTAR PUSTAKA}

1. Aritonang, Evawany.2011.Kebutuhan Gizi Ibu Hamil.Bogor:IPB Press.

2. Aziz, Alimul. 2007. Medode Penelitian Kebidanan Teknik Analisis Data. Jakarta: Salemba Medika.

3. Effendy. 2003. Ilmu Komunikasi Teori dan Praktik.Bandung : PT. Remaja.

4. Heriyanto, Bambang. 2012. Metode Penelitian Kuantitatif (Teori dan Aplikasi). Surabaya: Putra Media Nusantara.

5. Kristiyanasari,Weni.2014.Gizi Ibu Hamil. Jakarta:Nuha Medika.

6. Notoadmodjo, Soekidjo 2009. Promosi Kesehatan Teori dan Aplikasi. Jakarta: PT Rineka Cipta.

7. Notoadmodjo, Soekidjo. 2010. Pendidikan dan Perilaku Kesehatan. Jakarta: Rineka Cipta.

8. Proverawati, A, dan Wati, E.K. 2011.Ilmu Gizi untuk Keperawatan dan Gizi Kesehatan. Yogyakarta: Nuha Medika.

9. Proverawati, A. 2010. Nutrisi Janin dan Ibu Hamil. Yogyakarta: Nuha Medika.

10.Wawan dan Dewi. 2010. Pengetahuan, Sikap dan Perilaku Manusia.Yogyakarta : Nuha Medika. 